\title{
Policy Influence of Family Hope Program to Reduce the Poverty in Takalar, Indonesia
}

\author{
Nuryanti Mustari1 ${ }^{*}$, Lukman Hakim² ${ }^{\text {, Erni1 }}{ }^{1}$, Maharanny Puspaningrum1 \\ ${ }^{1}$ Department of Government Studies, Faculty of Social and Political Sciences, \\ Universitas Muhammadiyah Makassar, Jl. Sultan Alauddin No.259, Makassar 90221, Indonesia. \\ 2Department of Public Administration, Faculty of Social and Political Sciences, \\ Universitas Muhammadiyah Makassar, Jl. Sultan Alauddin No.259, Makassar 90221, Indonesia.
}

Received: 23 June 2019; Revised: 5 September 2019; Accepted: 30 October 2019

\begin{abstract}
This article analyze about policy influence of Family Hope Program toward reduce the poverty in Bontolebang Village, North Galesong Subdistrict. The methodology of this research is mix methods that combine quantitative and qualitative approach with questionnaire and interview instrument. The determination of sample in this research uses probability sampling techniques, the category of sample is beneficiary participant of the Family Hope Program but because the spectrum of population is too large so it just takes 80 people and 3 informants. Data collection technique are observation, questionnaire, interview, and documentation. Data analysis technique use regression analysis. Data validity technique are validity and reability testing. The result of this research indicate that policy influence of Family Hope Program in Bontolebang Village, North Galesong Subdistrict went very well. This is based on the average score obtained from statement item amounts 266,9 or 83,41\% which indicate that implementation of Family Hope Program occupies on the very good category. Afterwards, this research indicate that policy of Family Hope Program has positive and significant effect on poverty reduction amounts $62,7 \%$ and the rest amounts $37,3 \%$ caused by other programs from the government.
\end{abstract}

Keywords: Policy; Family Hope Program; Poverty

How to Cite: Mustari, N., Hakim, L., Erni, E., \& Puspaningrum, M. (2019). Policy Influence of Family Hope Program to Reduce the Poverty in Takalar, Indonesia. Otoritas : Jurnal Ilmu Pemerintahan, 9(2), 152-161.

Permalink/DOI: https://doi.org/10.26618/ojip.v9i2.2449

${ }^{*}$ Corresponding Author.

E-Mail : nuryantimustari@unismuh.ac.id

Copyright (C) 2019, Otoritas : Jurnal Ilmu Pemerintahan, ISSN: 2088-3706 (Print), ISSN: 2502-9320 (Online) 
Available Online at https://journal.unismuh.ac.id/index.php/otoritas

Otoritas : Jurnal Ilmu Pemerintahan, 9 (2), October 2019, 153

\section{INTRODUCTION}

The problem of poverty is still a major concern of the central and local governments in improving the welfare of society (Faried \& Alam, 2012; Faried, Alam, \& Wantu 2012). Various programs have been carried out by the government to overcome the problem of poverty. Poverty occurs due to the low quality of society's life, the low quality of life is influenced by low levels of education and health (Anggraeni, 2017). In an effort to reduce the poverty, the government rolled out the Family Hope Program Policy through Act No. 40 of 2004 concerning Social Security which is followed up by Presidential Regulation No. 15 of 2010 concerning the Acceleration of Poverty Reduction, and Minister of Social Affairs Regulation No. 10 of 2018 concerning the Family Hope Program (Suharto, 2015; Rahmawati \& Kisworo, 2017).

This study examines the Family Hope Program Policy. Previous research on the Family Hope Program in reduce poverty has been reviewed by Purwanto, Sumartono, \& Makmur (2013), in that research results show that the family hope program is able to change the mindset of the poor about the importance of education and health as a step to break the chain of poverty. In addition, the same study was carried out by Sahib (2016) which in the results of their research the government address the problem of poverty especially for basic health and education for children from poor families, the government provide assistance to society by meeting the specific requirements for receiving assistance. Then this research has been reviewed by Puspaningsih (2016) entitled Development of Poor Families through the Family Hope Program in Somba Opu Subdistrict, Gowa Regency. This research discusses the efforts of Family Hope Program in fostering poor families by approaching micro, mezzo, and macro according to the context of so- cial work.

However, it is different by the research conducted this current author, which leads to two variables that influencing and influenced in the Family Hope Program Policy. So the purpose of this research to discuss and study the influence of Family Hope Program Policy in reduce the poverty.

\section{RESEARCH METHODS}

This research uses a combination of quantitative and qualitative methods. This type of research uses survey methods, the data management is strengthened through observation and interviews. The data source is primary data which is the answer from the questionnaire and the results of interview while the secondary data by documentation, books, articles, journals, and internet websites related to this study.

Afterwards, this study uses the Probability Sampling technique with a simple random sampling method. The number of samples in this study are 80 people with sampling by numbering system that is raffled while the number of informants are 3 people. This study use regression analysis, to see the influence of Family Hope Program Policy variable to reduce the poverty. And to extent the causality between independent and dependent variables.

\section{RESULTS AND DISCUSSION}

\section{Policy of Family Hope Program in Ta- kalar, Indonesia}

Family Hope Program Policy is a program issued by the government to help underprivileged society (Sjafari, 2014). The Family Hope Program is a conditional assistance for underprivileged households who have family members such as toddlers, pregnant women, children from Elementary to Senor High School, and the elderly. 
Available Online at https://journal.unismuh.ac.id/index.php/otoritas

Otoritas : Jurnal Ilmu Pemerintahan, 9 (2), October 2019, 154

Table 1. Improving Social-Economic Condition

Source: Processed by the authors (2019)

\begin{tabular}{|c|c|c|c|c|c|c|c|c|c|c|c|c|}
\hline \multirow{2}{*}{ Statement } & \multicolumn{3}{|c|}{ SA (4) } & \multicolumn{3}{|c|}{ A (3) } & \multicolumn{3}{|c|}{ D (2) } & \multicolumn{3}{|c|}{ SD (1) } \\
\hline & $\Sigma$ & $\%$ & Score & $\Sigma$ & $\%$ & Score & $\Sigma$ & $\%$ & Score & $\Sigma$ & $\%$ & Score \\
\hline By Family Hope & & & & & & & & & & & & \\
\hline $\begin{array}{l}\text { Program can } \\
\text { improve the } \\
\text { economic of society }\end{array}$ & 49 & 61,25 & 196 & 31 & 38,75 & 93 & - & - & - & - & - & - \\
\hline $\begin{array}{l}\text { Changing the point of } \\
\text { view of society to be } \\
\text { independence }\end{array}$ & 26 & 32,5 & 104 & 44 & 55 & 132 & 10 & 12,5 & 20 & - & - & - \\
\hline $\begin{array}{l}\text { You and your family } \\
\text { have felt the welfare }\end{array}$ & 28 & 35 & 112 & 49 & 61,25 & 147 & 3 & 3,75 & 6 & - & - & - \\
\hline $\begin{array}{l}\text { Improving quality of } \\
\text { education and health }\end{array}$ & 36 & 45 & 144 & 44 & 55 & 132 & - & - & - & - & - & - \\
\hline $\begin{array}{l}\text { Get a briefing about } \\
\text { technology to be } \\
\text { advance }\end{array}$ & 47 & 58,75 & 188 & 31 & 38,75 & 93 & 1 & 1,25 & 2 & 1 & 1,25 & 1 \\
\hline Average & 37,2 & 46,5 & 148,8 & 39,8 & 49,75 & 119,4 & 4,67 & 5,83 & 9,33 & 1 & 1,25 & 1 \\
\hline
\end{tabular}

Table 2. Improving Level of Education

Source: Processed by the authors (2019)

\begin{tabular}{|c|c|c|c|c|c|c|c|c|c|c|c|c|}
\hline \multirow{2}{*}{ Statement } & \multicolumn{3}{|c|}{ SA (4) } & \multicolumn{3}{|c|}{ A (3) } & \multicolumn{3}{|c|}{ D (2) } & \multicolumn{3}{|c|}{ SD (1) } \\
\hline & $\Sigma$ & $\%$ & Score & $\Sigma$ & $\%$ & Score & $\Sigma$ & $\%$ & Score & $\Sigma$ & $\%$ & Score \\
\hline $\begin{array}{l}\text { There is no longer } \\
\text { children who do not } \\
\text { get } 12 \text { years compul- } \\
\text { sory education }\end{array}$ & 59 & 73,75 & 236 & 21 & 26,25 & 63 & - & - & - & - & - & - \\
\hline $\begin{array}{l}\text { Children who do not } \\
\text { complite their school } \\
\text { could attend the re- } \\
\text { medial program }\end{array}$ & 5 & 6,25 & 20 & 34 & 42,5 & 102 & 25 & 31,3 & 50 & 16 & 20 & 16 \\
\hline $\begin{array}{l}\text { Your children's } \\
\text { school need are fulfill }\end{array}$ & 41 & 51,25 & 164 & 45 & 3 & 135 & - & - & - & - & - & - \\
\hline $\begin{array}{l}\text { Relieve the burden of } \\
\text { parents }\end{array}$ & 59 & 73,75 & 236 & 20 & 25 & 60 & 1 & 1,25 & 2 & - & - & - \\
\hline Average & 41 & 51,25 & 164 & 30 & 24,19 & 90 & 13 & 16,3 & 26 & 16 & 20 & 16 \\
\hline
\end{tabular}


Available Online at https://journal.unismuh.ac.id/index.php/otoritas

Otoritas : Jurnal Ilmu Pemerintahan, 9 (2), October 2019, 155

Improving social-economic condition

A change or development experienced by people who were previously unable to fulfill their daily needs then now able to fulfill that. This is in line with Family Hope Program in the form of assistance for pregnant women, toddler, and children so they can fulfill their needs. The results of analysis indicators to improve socio-economic conditions can be seen by average of the highest respondents $49.75 \%$ who gave agreed responses, while the lowest average rating $1.25 \%$ of respondents who gave the assessment had less effect. Indicators of improving socio-economic conditions in the Bontolebang Village of North Galesong Subdistrict show that the assessment strongly agreed with $96.25 \%$ of respondents. The assessment obtained from the results of analysis 46.5\% strongly agree and there are $49.75 \%$ who agree. But there are several respondents amounts $7.08 \%$ which is obtained from the category of disagree and that is $5.83 \%$ disagree and $1.25 \%$ strongly disagree. This show indicators to improving the condition of socio-economic is in the category of strongly agree. The analysis results can be seen in the following table 1.

Improving level of education

Improving the level of education is expected to improve education for the future. So that the society can develop to fulfill their daily needs. This is in line with the Family Hope Program that one of the indicator is education. The result of analysis indicators to improving education level can be seen in the average of highest respondents $41 \%$ who gave agreed responses, while the lowest average rating of respondents $9 \%$ of respondents who gave a less influential assessment. Indicators of increasing the level of education in Bontolebang Villege of North Galesong Subdistrict show that the assessment strongly agreed amount $76 \%$ of respondents. The assessment obtained from the analysis result of $41 \%$ strongly agree and $36 \%$ agree. But there are several respondents amounts $24 \%$ which obtained from the category of disagree $15 \%$ and strongly disagree 9\%. This show indicators to improving level of education is in the category of strongly agree. The analysis results can be seen in the following table 2 .

Improving status of health

This is in line with Family Hope Program that the one of its indicator is improvement of health service. By Family Hope Program, it is expected to be able to improve the service in Public Health Center and Hospital. The result of analysis indicators to improving education level can be seen in the average of highest respondents $39.75 \%$ who gave agreed responses, while the lowest average rating of respondents $2.5 \%$ who gave a less influential assessment. Indicators of increasing the level of education in Bontolebang Villege of North Galesong Subdistrict show that the assessment strongly agreed amount $92 \%$ of respondents. The assessment obtained from the analysis result of $39.75 \%$ strongly agree and $52.25 \%$ who agree. But there are several respondents amounts $8.25 \%$ which obtained from the category of disagree $5.75 \%$ and strongly disagree $2.5 \%$. This show indicators to improving status of health is in the category of strongly agree. The analysis results can be seen in the following table 3 .

Improving access and quality of services

Improving access and quality of service is one of the indicators that exist in variable implementation of Family Hope Program. The analysis result of indicators increasing access and quality of service can be seen in the average of the highest respondents amount $55.25 \%$ of respondents who gave agreed responses, while the lowest average rating of respondents amount $1.25 \%$ of respondents who gave a less influential assessment. Indicators of improving access and quali- 
Available Online at https://journal.unismuh.ac.id/index.php/otoritas

Otoritas : Jurnal Ilmu Pemerintahan, 9 (2), October 2019, 156

Table 3. Improving Status of Health

Source: Processed by the authors (2019)

\begin{tabular}{|c|c|c|c|c|c|c|c|c|c|c|c|c|}
\hline \multirow{2}{*}{ Statement } & \multicolumn{3}{|c|}{ SA (4) } & \multicolumn{3}{|c|}{ A (3) } & \multicolumn{3}{|c|}{ D (2) } & \multicolumn{3}{|c|}{ SD (1) } \\
\hline & $\Sigma$ & $\%$ & Score & $\Sigma$ & $\%$ & $\Sigma$ & $\%$ & Score & $\Sigma$ & $\Sigma$ & & $\%$ \\
\hline $\begin{array}{l}\text { Newborns get a } \\
\text { good care }\end{array}$ & 43 & 53,75 & 172 & 37 & 46,25 & 111 & - & - & - & - & - & - \\
\hline $\begin{array}{l}0-6 \text { years old of } \\
\text { children always } \\
\text { get a medical } \\
\text { check up }\end{array}$ & 39 & 48,75 & 156 & 39 & 48,75 & 117 & 1 & 1,25 & 2 & 1 & 1,25 & 1 \\
\hline $\begin{array}{l}\text { Pregnant women } \\
\text { always do a } \\
\text { complete medical } \\
\text { check up }\end{array}$ & 39 & 48,75 & 156 & 41 & 51,25 & 123 & - & - & - & - & - & - \\
\hline $\begin{array}{l}\text { Nutrition of } \\
\text { nursing mother } \\
\text { is fulfilled }\end{array}$ & 30 & 37,5 & 36 & 50 & 62,5 & 150 & - & - & - & - & - & - \\
\hline $\begin{array}{l}\text { Person with } \\
\text { disabilities can } \\
\text { check up their } \\
\text { health in a } \\
\text { specialist }\end{array}$ & 16 & 20 & 64 & 52 & 65 & 156 & 9 & 11,25 & 18 & 3 & 3,75 & 3 \\
\hline Average & 33,4 & 41,75 & 116,8 & 43,8 & 54,75 & 131,4 & 5 & 6,25 & 10 & 2 & 2,5 & 2 \\
\hline
\end{tabular}

Table 4. Improving Access and Quality of Service

Source: Processed by the authors (2019)

\begin{tabular}{|c|c|c|c|c|c|c|c|c|c|c|c|c|}
\hline \multirow{2}{*}{ Statement } & \multicolumn{3}{|c|}{ SA (4) } & \multicolumn{3}{|c|}{ A (3) } & \multicolumn{3}{|c|}{ D (2) } & \multicolumn{3}{|c|}{ SD (1) } \\
\hline & $\Sigma$ & $\%$ & Score & $\Sigma$ & $\%$ & Score & $\Sigma$ & $\%$ & Score & $\Sigma$ & $\%$ & Score \\
\hline $\begin{array}{l}\text { Education and } \\
\text { helath are easir } \\
\text { to access }\end{array}$ & 52 & 65 & 208 & 27 & 33,75 & 81 & 1 & 1,25 & 2 & - & - & - \\
\hline $\begin{array}{l}\text { Health services } \\
\text { in Public Health } \\
\text { Center to be } \\
\text { better }\end{array}$ & 46 & 57,5 & 184 & 34 & 42,5 & 102 & - & - & - & - & - & - \\
\hline $\begin{array}{l}\text { Become more } \\
\text { independent in } \\
\text { taking care of } \\
\text { matters at } \\
\text { Public Health } \\
\text { Center }\end{array}$ & 33 & 41,25 & 132 & 45 & 56,25 & 135 & 1 & 1,25 & 2 & 1 & 1,25 & 1 \\
\hline $\begin{array}{l}\text { Knowing about } \\
\text { technology so } \\
\text { do not left by } \\
\text { the changes }\end{array}$ & 18 & 22,5 & 72 & 53 & 66,25 & 159 & 9 & 11,25 & 18 & - & - & - \\
\hline $\begin{array}{l}\text { Giving facility to } \\
\text { people with } \\
\text { disabillities to } \\
\text { get health } \\
\text { services and } \\
\text { education }\end{array}$ & 12 & 15 & 48 & 62 & 77,5 & 186 & 5 & 6,25 & 10 & 1 & 1,25 & 1 \\
\hline Average & 32,2 & 40,25 & 128,8 & 44,2 & 55,25 & 132,6 & 4 & 5 & 8 & 1 & 1,25 & 1 \\
\hline
\end{tabular}


ty of services in the Bontolebang Village of North Galesong Subdistrict indicate that the assessment strongly agreed by $95.5 \%$ of respondents. The assessment obtained from the analysis of $40.25 \%$ strongly agree and $55.25 \%$ who agree. But there are several respondents amounts 5\% obtained from the category of disagree $5 \%$ and strongly disagree $1.25 \%$. This show indicators to improving access and quality of services is in the category of strongly agree. The analysis results can be seen in the following table 4 .

\section{Poverty Reduction Efforts in Takalar, In- donesia}

Poverty reduction is an incessant effort to reduce poverty in the Bontolebang Village, North Galesong Subdistrict. The indicators of poverty reduction efforts are basic needs fulfillment, education needs fulfillment, and health needs fulfillment.

\section{Basic needs fulfillment}

This is primary needs that must be existed on daily basis. Primary needs consist of clothing, food, and shelter. The analysis results of basic needs fulfillment indicators show the highest average is $41 \%$ of respondents agree, whereas the lowest average is $9.25 \%$ of respondents disagree. The indicator of basic needs fulfillment in Bontolebang Village, North Galesong Subdistrict indicates 65\% of respondents strongly agreed. This is obtained from the analysis of $24 \%$ of respondents who strongly agreed and $41 \%$ of respondents who agreed.

But there are still $35.25 \%$ of respondents disagree which is obtained from $26 \%$ of respondents disagree and $9.25 \%$ of respondents strongly disagree. This shows the indicator of basic needs fulfillment is in the medium category, due to the fact that there are still people who do not have a decent place to live because they are not be able to afford a land. In the end, people build house on other's land so that they are not entitled to repair their house by government assistance. The analysis results can be seen in the following table 5.

\section{Education needs fulfillment}

Education is one of the many factors that can improve people's lives. The analysis results of education needs fulfillment indicators show the highest average is $50 \%$ of respondents agree, whereas the lowest average is $2.5 \%$ of respondents disagree. The indicator of education needs fulfillment in Bontolebang Village, North Galesong Subdistrict indicates $98.5 \%$ of respondents strongly agreed. This is obtained from the analysis of $48.5 \%$ of respondents strongly agree and $50 \%$ of respondents agree.

But there are still $2.5 \%$ of respondents who disagreed which is obtained from $2.5 \%$ of respondents who strongly disagree. It is because the parents' ability to fulfill their children's school needs is low, refer to many school needs must be met. It is because the parents' ability to fulfill their children's school needs is low, refer to many school needs must be met. As well, children's interests in schools are also low thus children do not want to go to school. The analysis results can be seen in the following table 6 .

Based on the table, indicators of fulfilling educational needs with 5 types of questions on 80 respondents found $48.5 \%$ of respondents strongly agree, $50 \%$ of respondents agree, and $2.5 \%$ of respondents disagree.

Health needs fulfillment

Health needs fulfillment is an essential and significant needs on a person's survival. Because if only focus at work and ignore our health condition, it is wasted. The analysis results of health needs fulfillment indicators show the highest average is $49.75 \%$ of respondents agree, whereas the lowest average is $1.25 \%$ of respondents disagree. The indi- 
Available Online at https://journal.unismuh.ac.id/index.php/otoritas

Otoritas : Jurnal Ilmu Pemerintahan, 9 (2), October 2019, 158

Table 5. Basic Needs Fulfillment

Source: Processed by the authors (2019)

\begin{tabular}{|c|c|c|c|c|c|c|c|c|c|c|c|c|}
\hline \multirow{2}{*}{ Statement } & \multicolumn{3}{|c|}{ SA (4) } & \multicolumn{3}{|c|}{ A (3) } & \multicolumn{3}{|c|}{ DA (2) } & \multicolumn{3}{|c|}{ SD (1) } \\
\hline & $\Sigma$ & $\%$ & Score & $\Sigma$ & $\%$ & Score & $\sum$ & $\%$ & Score & $\Sigma$ & $\%$ & Score \\
\hline $\begin{array}{l}\text { Your family's daily } \\
\text { food needs are } \\
\text { enough }\end{array}$ & 43 & 53,75 & 172 & 36 & 45 & 108 & 1 & 1,25 & 2 & - & - & - \\
\hline $\begin{array}{l}\text { Your daily food } \\
\text { consists of } 5 \text { main } \\
\text { components of } \\
\text { food (staple, side } \\
\text { dish, vegetables } \\
\text { dish, and be able } \\
\text { to supply dairy } \\
\text { needs) }\end{array}$ & 44 & 55 & 176 & 35 & 43,75 & 105 & 1 & 1,25 & 2 & - & - & - \\
\hline $\begin{array}{l}\text { All of your family } \\
\text { members are able } \\
\text { to fulfill daily } \\
\text { needs }\end{array}$ & 41 & 51,25 & 164 & 39 & 48,75 & 117 & - & - & - & - & - & - \\
\hline $\begin{array}{l}\text { All of your family } \\
\text { members each } \\
\text { have different } \\
\text { clothes at home, } \\
\text { work, and school }\end{array}$ & 12 & 15 & 48 & 64 & 80 & 192 & 4 & 5 & 8 & - & - & - \\
\hline $\begin{array}{l}\text { You have a decent } \\
\text { place to live }\end{array}$ & 54 & 67,5 & 216 & 26 & 32,5 & 78 & - & - & 0 & - & - & - \\
\hline Average & 38,8 & 48,5 & 155,2 & 40 & 50 & 120 & 2 & 2,5 & 2,4 & - & - & - \\
\hline
\end{tabular}

Table 6. Education Needs Fulfillment

Source: Processed by the authors (2019)

\begin{tabular}{|c|c|c|c|c|c|c|c|c|c|c|c|c|}
\hline \multirow{2}{*}{ Statement } & \multicolumn{3}{|c|}{ SA (4) } & \multicolumn{3}{|c|}{$A(3)$} & \multicolumn{3}{|c|}{ DA (2) } & \multicolumn{3}{|c|}{ SD (1) } \\
\hline & $\Sigma$ & $\%$ & Score & $\Sigma$ & $\%$ & Score & $\Sigma$ & $\%$ & Score & $\Sigma$ & $\%$ & Score \\
\hline $\begin{array}{l}\text { With the Family } \\
\text { Hope Program, } \\
\text { you can fulfill your } \\
\text { children's school } \\
\text { needs }\end{array}$ & 43 & 53,75 & 172 & 36 & 45 & 108 & 1 & 1,25 & 2 & - & - & - \\
\hline $\begin{array}{l}\text { Your children's } \\
\text { basic education is } \\
\text { fulfilled }\end{array}$ & 44 & 55 & 176 & 35 & 43,75 & 105 & 1 & 1,25 & 2 & - & - & - \\
\hline $\begin{array}{l}\text { With the Family } \\
\text { Hope Program, } \\
\text { your children's } \\
\text { school attendance } \\
\text { are improving }\end{array}$ & 41 & 51,25 & 164 & 39 & 48,75 & 117 & - & - & - & - & - & - \\
\hline $\begin{array}{l}\text { Your children are } \\
\text { doing well in } \\
\text { school }\end{array}$ & 12 & 15 & 48 & 64 & 80 & 192 & 4 & 5 & 8 & - & - & - \\
\hline $\begin{array}{l}\text { Your expenses are } \\
\text { reduced }\end{array}$ & 54 & 67,5 & 216 & 26 & 32,5 & 78 & - & - & 0 & - & - & - \\
\hline Average & 38,8 & 48,5 & 155,2 & 40 & 50 & 120 & 2 & 2,5 & 2,4 & - & - & - \\
\hline
\end{tabular}


cator of health needs fulfillment in Bontolebang Village, North Galesong Subdistrict indicates $98.75 \%$ of respondents strongly agreed. This is obtained from the analysis of $49 \%$ of respondents strongly agree and $49.75 \%$ of respondents agree.

But there are still $3.75 \%$ of respondents disagree which is obtained from $2.5 \%$ of respondents disagree and $1.25 \%$ of respondents totally disagree. This is because there are still people who when they are sick, they do not want to go to the health center. Moreover, children also do not get their rights in health checks because of busy parents. The analysis results can be seen in the following table 7 .

\section{The Effects of Family Hope Program Policies on Poverty Reduction in Ta- kalar, Indonesia}

To see the effect of Family Hope Program policy on poverty reduction, a regression analysis was carried out on 80 respondents using SPSS Statistic 21. The regression analysis obtained as table 8.

To find out effect of the Family Hope Program on poverty reduction, it can be analyzed using simple regression. It analyzed the independent variable (X), the Family Hope Program policy, on the dependent variable (Y), poverty reduction in the Bontolebang Village, North Galesong District.

As we can see in the Anova table above, the calculated F-value $=50.606$ with a significant level $0,000<0.05$, so the variable of Family Hope Program policy (X) affects the variable of poverty reduction (Y). It indicates Ha is accepted and Ho is rejected because the Sig value is smaller than 0.05 .

On the coefficients table 9 , the Constant value (a) is 4.868 , whereas the value of the Family Hope Program policy (regression coefficient) is 0.657 . To deter-

Table 7. Health Needs Fulfillment

Source: Processed by the authors (2019)

\begin{tabular}{|c|c|c|c|c|c|c|c|c|c|c|c|c|}
\hline \multirow{2}{*}{ Statement } & \multicolumn{3}{|c|}{ SA (4) } & \multicolumn{3}{|c|}{ A (3) } & \multicolumn{3}{|c|}{$D(2)$} & \multicolumn{3}{|c|}{ SD (1) } \\
\hline & $\Sigma$ & $\%$ & Score & $\Sigma$ & $\%$ & Score & $\Sigma$ & $\%$ & Score & $\Sigma$ & $\%$ & Score \\
\hline $\begin{array}{l}\text { Hope Family Assistance } \\
\text { Program can help to } \\
\text { meet the nutritional } \\
\text { needs of pregnant } \\
\text { women and toddler }\end{array}$ & 37 & 46,25 & 148 & 43 & 53,75 & 129 & - & - & - & - & - & - \\
\hline $\begin{array}{l}\text { If you / your child is } \\
\text { sick, you do not have } \\
\text { problems to seek } \\
\text { treatment }\end{array}$ & 46 & 57,5 & 184 & 34 & 42,5 & 102 & - & - & - & - & - & - \\
\hline $\begin{array}{l}\text { You become more } \\
\text { frequent to do health } \\
\text { check-up in health } \\
\text { center and other health } \\
\text { posts. }\end{array}$ & 41 & 51,25 & 164 & 37 & 46,25 & 111 & 2 & 2,5 & 4 & - & - & - \\
\hline $\begin{array}{l}\text { Toddlers get an } \\
\text { adequate nutritional } \\
\text { fulfillment }\end{array}$ & 25 & 31,25 & 100 & 54 & 67,5 & 162 & - & - & - & 1 & 1,25 & 1 \\
\hline $\begin{array}{l}\text { There are no gaps in the } \\
\text { delivery of health } \\
\text { services }\end{array}$ & 47 & 58,75 & 188 & 31 & 38,75 & 93 & 2 & 2,5 & 4 & - & - & - \\
\hline Average & 39,2 & 49 & 156,8 & 39,8 & 49,75 & 119,4 & 2 & 2,5 & 1,6 & 1 & 1,25 & 1 \\
\hline
\end{tabular}


Available Online at https://journal.unismuh.ac.id/index.php/otoritas

Otoritas : Jurnal Ilmu Pemerintahan, 9 (2), October 2019, 160

mine the amount of the variable $X$ and variable $\mathrm{Y}$ effects, a simple regression equation model formula is used as follows:

$$
\begin{aligned}
\mathrm{Y} & =\mathrm{a}+\mathrm{bX} \\
\mathrm{Y} & =4.868+0.657 \mathrm{X}
\end{aligned}
$$

Based on the simple regression equation, the regression coefficient (b) is 4.868, it shows the independent variable or the Family Hope Program policy (X) has a positive effect on the dependent variable or poverty reduction (Y). Moreover, the regression coefficient value is
0.657 that indicates the implementation of the Family Hope Program in the Bontolebang Village, North Galesong District will increase by 0.657 .

The results of $\mathrm{t}$ arithmetic is 4,868 or the significant (Sig) is 0.000 smaller than $<0.05$, so that $\mathrm{Ha}$ is accepted. It means the Family Hope Program policy has a significant effect on poverty reduction efforts in the Bontolebang Village, North Galesong District.

The results of the hypothesis, $\mathrm{Ha}$ is accepted. It shows the Family Hope Pro-

Table 8. F-test Results

Source: Processed by the authors (2019)

ANOVA $^{\mathrm{a}}$

\begin{tabular}{cccccc}
\hline Model & Sum of Squares & Df & Mean Square & F & Sig. \\
\hline Regression & 1001,366 & 1 & 1001,366 & 50,606 &, $000^{\mathrm{b}}$ \\
Residual & 1543,434 & 78 & 19,788 & & \\
Total & 2544,800 & 79 & & & \\
\hline
\end{tabular}

Table 9. Simple Regression Results

Source: Processed by the authors (2019)

\begin{tabular}{|c|c|c|c|c|c|}
\hline \multirow[t]{2}{*}{ Model } & \multicolumn{2}{|c|}{$\begin{array}{l}\text { Unstandardized } \\
\text { Coefficients }\end{array}$} & \multirow{2}{*}{$\begin{array}{c}\text { Standardized } \\
\text { Coefficients } \\
\text { Beta }\end{array}$} & \multirow[t]{2}{*}{$T$} & \multirow[t]{2}{*}{ Sig. } \\
\hline & B & Std. Error & & & \\
\hline (Constant) & 4,868 & 6,182 & & ,788 & ,433 \\
\hline $\begin{array}{l}\text { The Policy of Family Hope } \\
\text { Program }\end{array}$ & 657 & 092 & 627 & 7,114 & 000 \\
\hline
\end{tabular}

Coefficients $^{\mathrm{a}}$

a. Dependent Variable: Poverty Reduction

Table 10. Determinant Correlation Test Results

Source: Processed by the authors (2019)

Model Summary

\begin{tabular}{ccccc}
\hline Model & R & R Square & Adjusted R Square & Std. Error of the Estimate \\
\hline 1 &, $627^{\mathrm{a}}$ &, 393 &, 386 & 4,44833 \\
\hline
\end{tabular}

a. Predictors: (Constant), Family Hope Program Policy 
Available Online at https://journal.unismuh.ac.id/index.php/otoritas

Otoritas : Jurnal Ilmu Pemerintahan, 9 (2), October 2019, 161

gram policy have a strong effect on poverty reduction efforts.

Based on the data analysis, it shows the amount of variable $X$ effects contribution on the variable $Y$. The effect is symbolized by $\mathrm{R}$ (regression). As in the table above it explains that the amount of the regression value or influence $(R)$ is 0.627 or $62.7 \%$. The amount of the independent variable or the Family Hope Program Policy (X) effects on the dependent variable or poverty reduction efforts (Y) is also strengthened by the Adjusted $\mathrm{R}$ Square value 0.386 or $38.6 \%$. The data is fairly good or moderate level according to table 3.2, it is also proven in the Standard Error column of 4.44833 , that the more value approaches 0 , the more accurate the data.

\section{CONCLUSION}

Based on the implementation of all its activities, the Family Hope Program policy in the Bontolebang Village, North Galesong District has been going well. Poverty reduction efforts in the Bontolebang Village of North Galesong District through the Family Hope Program can reduce the underprivileged society's burden. The Family Hope Program policy has a positive effect on poverty reduction in the Bontolebang Village with the amount of effect amounts 0.627 or $62.7 \%$.

\section{ACKNOWLEDGEMENT}

We would like to express our gratitude to Universitas Muhammadiyah Makassar, Indonesia.

\section{REFERENCES}

Anggraeni, F. N. (2017). Readiness to Use E-Money as a Family Hope Program Fund Distribution Facility. Economics Development Analysis Journal, 6(1), 40-47.

Faried, A., \& Alam, A. S. (2012). Government Policy Studies.
Bandung: Refika Aditama Corp.

Faried, A., Alam, A. S., \& Wantu, S. W. (2012). Policy Analysis Study: Concepts, Theories and Applications of Government Policy Analysis Techniques. Bandung: Refika Aditama Corp.

Purwanto, S. A., Sumartono, S., \& Makmur, M. (2013). Implementasi Kebijakan Program Keluarga Harapan (PKH) Dalam Memutus Rantai Kemiskinan (Kajian di Kecamatan Mojosari Kabupaten Mojokerto). WACANA, Jurnal Sosial dan Humaniora, 16 (2), 79-96.

Puspaningsih, C. (2016). Developing Underprivilege Families through the Family Hope Program in Somba Opu District of Gowa Regency (Bachelor Thesis, Universitas Islam Negeri Alauddin Makassar).

Rahmawati, E., \& Kisworo, B. (2017). The Role of Companion in Empowering the Underprivilege Through the Family Hope Program. Journal of Nonformal Education and Community Empowerment, 1(2), 161-169.

Sahib, M. (2016). The Effect of Family Hope Program Policies on Poverty Reduction in Bajeng District, Gowa Regency (Bachelor Thesis, Universitas Islam Negeri Alauddin Makassar).

Suharto, E. (2015). The Role of Social Protection in Overcoming Poverty in Indonesia: Case Study of Family Hope. Sosiohumaniora, 17(1), 2127.

Sjafari, A. (2014). Poverty and People Empowerment. Yogyakarta: Graha Ilmu. 